\title{
Evaluation of Neutrophil/Lymphocyte Ratio, Thrombocyte/ Lymphocyte Ratio and Mean Platelet Volume in Children with Rotavirus Gastroenteritis
}

\author{
Rotavirüs Gastroenteritli Çocuklarda Nötrofil/ Lenfosit Oranı, Trombosit/ \\ Lenfosit Oranı ve Ortalama Trombosit Hacminin Değerlendirilmesi
}

\author{
(1) Alaaddin Yorulmaz'
}

'Selçuk University Medical Faculty, Department of Pediatrics, Konya, Turkey

\begin{abstract}
Objective: Rotavirus is most common agent responsible for acute gastroenteritis in Turkey as its in the world. The aim of this study is to compare the values of neutrophil/lymphocyte ratio, platelet/lymphocyte ratio and mean platelet volume in patients with rotavirus gastroenteritis with healthy controls.

Material and Method: Patients with acute rotavirus gastroenteritis, who were admitted to our Department of Pediatric Health and Diseases between January 2016 and January 2017, were included in this study. Patients' data were reviewed, retrospectively. Age, gender, seasonal distribution, symptoms, duration of hospitalization, course of disease, type of acute gastroenteritis, frequency of nosocomial infections and complications were investigated. Adeno/Rota combi test kit, a solid phase immunochromatographic test, was used to investigate the gastroenteritis-factor rotavirus in all samples.

Results: 210 patients diagnosed with rotavirus gastroenteritis were included in the study. $116(55.2 \%)$ of the patients were male and 94 (44.8\%) were female. A total of 160 healthy children (102 males (63.8\%), 58 females (36.2\%), mean age $39.91 \pm 16.86$ months) were included in the control group. The mean age of our patients was $39.09 \pm 17.64$ months. There was no statistically significant difference between genders in terms of mean ages ( $p: 0.771$ ) According to frequency of complaints at the admission, all of our patients had diarrhea (100\%), 188 (89.5\%) patients had vomiting, 55 (26.2\%) patients had abdominal pain and $62(29.5 \%)$ patients had fever. There was no statistically significant difference in terms of symptoms between the age groups ( $p>$ 0.05). Mean length of hospitalization of patients was $3.75 \pm 2.03$ days.

Conclusion: In our study, neutrophil/lymphocyte ratio, platelet/lymphocyte ratio and mean platelet volume values were found statistically higher in patients with rotavirus-associated gastroenteritis than in healthy subjects. We think that these parameters will be indicative to predict the course of the disease and complications.
\end{abstract}

Keywords: Rotavirus, gastroenteritis, MPV, child

\section{ÖZ}

Amaç: Rotavirüs, dünyada olduğu gibi Türkiye'de de akut gastroenteritlerden en sık sorumlu ajandır. Bu çalışmanın amacı rotavirüs gastroenteritli hastalarda nötrofil/lenfosit oranı, trombosit/lenfosit oranı ve ortalama trombosit hacminin sağlıklı kontrollerle karşılaştırmaktır.

Gereç ve Yöntem: Ocak 2016-Ocak 2017 tarihleri arasında Çocuk Sağlığı ve Hastalıkları Anabilim Dalı'na başvuran akut rotavirüs gastroenteritli hastalar çalışmaya dahil edildi. Hastaların verileri retrospektif olarak incelendi. Yaş, cinsiyet, mevsimsel dağılım, semptomlar, hastanede yatış süresi, hastalık seyri, akut gastroenterit tipi, hastane infeksiyonu sıklığı ve komplikasyonları araştırıldı. Tüm örneklerde gastroenterit faktörü rotavirüsünü araştırmak için katı fazlı immünokromatografik test olan Adeno/Rota kombi test kiti kullanıldı.

Bulgular: Çalışmaya rotavirüs gastroenteriti tanısı konan 210 hasta dahil edildi. Hastaların 116'sı (\% 55,2) erkek, 94'ü (\% 44,8) kadındı. Kontrol grubuna toplam 160 sağlıklı çocuk (102 erkek (\% 63.8), 58 kadın (\% 36.2), yaş ortalaması $39.91 \pm 16.86$ ay) dahil edildi. Hastalarımızın yaş ortalaması $39.09 \pm 17.64$ ay idi. Cinsiyete göre yaş ortalamaları açısından istatistiksel olarak anlamlı bir fark saptanmadı (p: 0,771). Başvuru sırasındaki şikayet sıklığına göre tüm hastalarımızda ishal (\% 100), 188 (\% 89,5) hastada kusma, 55 (\% 26,2) hastada karın ağrısı ve $62(\% 29,5)$ hastada ateş vardı. Yaş grupları arasında semptomlar açısından istatistiksel olarak anlamlı fark yoktu ( $p$ > 0.05). Hastaların ortalama yatış süresi 3,75 $\pm 2,03$ gündü.

Sonuç: Çalışmamızda rotavirüs ile ilişkili gastroenteritli hastalarda nötrofil/ lenfosit oranı, trombosit/lenfosit oranı ve ortalama trombosit hacmi değerleri sağlıklı çocuklara göre daha yüksek bulundu. Bu parametrelerin hastalığın seyrini ve komplikasyonlarını öngörmede belirleyici olacağını düşünüyoruz.

Anahtar Kelimeler: Rotavirüs, gastroenterit, MPV, çocuk 


\section{INTRODUCTION}

Acute gastroenteritis is a major cause of morbidity and mortality in children of all ages (1). Viral pathogens are known as the most common etiologic factors. Among the viral agents, rotavirus, which is a member of the reoviridae family, has been identified as the most frequent pathogen. Rotavirus diarrhea is widespread throughout the world, regardless of socioeconomic status and developmental levels. Clinical features range from asymptomatic infection, to severe dehydration and shock, and, in some cases, death. Clinically significant gastroenteritis cases are frequently seen in infants under the age of five, particularly in infants between 6 and 24 months of age (2).

Previous studies have addressed whether rotavirus infection is confined to the intestine (3). Rotavirus genome isolated from the cerebrospinal fluid and serum, and the detection of live virus in the blood of infected children, has indicated that rotavirus can escape from the gastrointestinal tract into the circulatory system and even enter other organs (4).

Antigenemia is commonly detected in rotavirus-infected children $(5,6)$. In the acute phase of infection, the detection of serum rotavirus antigen ranges from $43-$ $90 \%$. Rotavirus antigen levels usually peak 1 to 3 days after symptom onset and are undetectable beyond 1 week (7). Antigenemia level is reported to be directly associated with antigen levels in stools, and inversely related to the titer of specific anti-rotavirus antibodies in the serum (8). Cytokines, as the products of host response to inflammation, play an important role in the defense against infections. Cytokines mediate the inflammatory process and may influence the pathogenesis of rotavirus (9).

In recent years, an easy and practical method that provides valuable information for diagnosing various diseases and determining their prognosis, becomes a current issue. It is suggested that parameters of the hemogram, including mean platelet volume (MPV), neutrophil/lymphocyte ratio (NLR) and platelet/ lymphocyte ratio (PLR) may be used for diagnosis and follow-up of inflammation. NLR is generally considered to be indicative of subclinical inflammation. Similarly, MPV has been reported to increase in various vascular and inflammatory diseases.

There are very few studies evaluating the relationship between MPV, NLR and PLR in patients with rotavirusinduced gastroenteritis. Our aim is to determine whether rotavirus viremia changes these haematological parameters in patients diagnosed with rotavirus and its prognostic importance. We aimed to compare MPV, NLR and PLR values in patients with rotavirus gastroenteritis with healthy controls.

\section{MATERIALS AND METHODS}

210 patients aged between 1 months-16 years with acute rotavirus gastroenteritis, who were admitted to our Department of Pediatric Health and Diseases between January 2016 and January 2017, were included in this study. Patients' data were reviewed, retrospectively. Age, gender, seasonal distribution, symptoms, duration of hospitalization, course of disease, type of acute gastroenteritis, frequency of nosocomial infections and complications were investigated. Our patients were classified into three groups according to their age: 0-24 months, 25-60 months, > 60 months.

Patients with chronic disease, immunodeficiency, malnutrition, chronic gastroenteritis were excluded from the study. If there is any other causes of leukocytosis, they were not included in the study.

Control group was constituted of outpatient healthy children, who did not have any chronic illness or sign of infection and undergoing blood analyses for other reasons.

The diagnosis of acute gastroenteritis was made under the condition that the patient having to defecate watery gaita more than 3 times a day, increased gaita fluid content and, the diarrhea, vomiting, fever and other complaints not exceeding 14 days. Patients who did not have gastroenteritis prior to hospital admission and developed a gastroenteritis clinic due to different reasons, three days after admission to the hospital, were accepted as nasocomial infections.

Complete blood count, levels of serum electrolytes, glucose, urea, liver function tests, stool tests of patients were reviewed. The complete blood count analyses were performed in Coulter analyzer Sysmex XN-1000, Sysmex Corporation, Kobe, Japan in the central laboratory of our institution. The white blood cell (KuL), neutrophil (K/uL) count, lymphocyte (K/uL) count, platelet (K/uL) count and MPV (fL), PDW ( $f L)$ and PCT ( $\mu \mathrm{g} / \mathrm{L}$ ) values were obtained from the hemogram results. Neutrophil -lymphocyte ratio (NLR) was calculated as the ratio of the neutrophils and lymphocytes both obtained from blood sample at admission. PLR was calculated by dividing platelet count by lymphocyte count.

Collection of Samples: Stool specimens were taken with sterile, screw cap sample collection containers, from the patients included in the study. Immediately after the stool samples were taken, they were examined in terms of viral gastroenteritis factors in our hospital microbiology laboratory.

Identification of Viral Factors: Adeno/Rota combi test kit (immunochromatography assay kits Rapid Testa ROTA$\mathrm{ADENO}^{\circledR}, \mathrm{China}$ ), a solid phase immunochromatographic test, was used to investigate the gastroenteritis-factor rotavirus in all samples. Sensitivity and specificity for rotavirus were $97.3 \%$ and $98.3 \%$, respectively. 
Ethics committee approval of the study was taken from the ethics committee of Selçuk University.

\section{Statistical Analysis}

Statistical methods of descriptive data were shown with mean \pm standard deviation. Kolmogorow-Smirnov and Shapiro-Wilk normality tests were performed to determine whether the data were corresponding to normal distributions. Parametric data were analyzed using Student's t-test, nonparametric data were performed with chi-square test, Mann-Whitney $U$ test. The Kruskal-Wallis test was used to compare the groups. Level of significance was assessed at $p<0.05$. Spearman correlation test was applied for correlation analysis. The data obtained in the study were analyzed using SPSS 15.0 (SPSS Inc, Chicago, Illinois, United States of America) package computer program(software) for statistical analysis.

\section{RESULTS}

In the study period, the total number of patients hospitalized for various reasons was 3985 , while $5.26 \%$ of these cases were due to rotavirus gastroenteritis. Of the patients, 116 (55.2\%) were male and 94 (44.8\%) were female. Mean age of our patients was $39.09 \pm 17.64$ months. A total of 160 healthy children (102 males (63.8\%), 58 females (36.2\%), mean age $39.91 \pm 16.86$ months) appeal to pediatric outpatient clinics for routine control and screening, were included in the control group. The demographic characteristics of our patients are summarized in Table 1. There was no statistically significant difference between genders in terms of mean ages ( $p: 0.771)$. When we distribute the patients according to age groups; there were 38 patients (18.1\%) between 0-24 months, 145 patients (69.0\%) between 24 60 months and 27 patients (12.9\%) over 60 months.

\begin{tabular}{|c|c|c|c|}
\hline & $\begin{array}{c}\text { Patient Group } \\
\text { N (\%) }\end{array}$ & $\begin{array}{c}\text { Control Group } \\
\mathbf{N}(\%)\end{array}$ & $\mathbf{P}$ \\
\hline $\begin{array}{l}\text { Gender } \\
\text { Female } \\
\text { Male }\end{array}$ & $\begin{array}{c}94(44.8 \%) \\
116(55.2 \%)\end{array}$ & $\begin{array}{c}58(36.3 \%) \\
102(63.8 \%)\end{array}$ & 0.980 \\
\hline $\begin{array}{l}\text { Age Groups } \\
0-24 \text { month } \\
24-60 \text { month } \\
>60 \text { month }\end{array}$ & $\begin{array}{c}38(18.1 \%) \\
145(69.0 \%) \\
27(12.9 \%)\end{array}$ & $\begin{array}{c}24(15.0 \%) \\
116(72.5 \%) \\
20(12.5 \%)\end{array}$ & 0.711 \\
\hline $\begin{array}{l}\text { Season } \\
\text { Winter } \\
\text { Spring } \\
\text { Summer } \\
\text { Autumn }\end{array}$ & $\begin{array}{c}77(\% 36.7) \\
100(\% 47.6) \\
22(10.5 \%) \\
11(5.2 \%)\end{array}$ & & \\
\hline $\begin{array}{l}\text { Symptom } \\
\text { Vomiting } \\
\text { Fever } \\
\text { Abdominal pain }\end{array}$ & $\begin{array}{l}188(89.5 \%) \\
62(29.5 \%) \\
55(26.2 \%)\end{array}$ & & \\
\hline
\end{tabular}

According to frequency of complaints at the admission, all of our patients had diarrhea (100\%), 188 (89.5\%) patients had vomiting, 55 (26.2\%) patients had abdominal pain and 62 (29.5\%) patients had fever. There was no statistically significant difference in terms of symptoms between the age groups ( $p>0.05)$. Mean length of hospitalization of patients was $3.75 \pm 2.03$ days. There was no statistically significant difference between the males and females in terms of hospitalization time (p:0.906). The hospitalization times in the 0-24 month, 25-60 month, and $>60$ month age groups were 3.89 \pm 2.05 days, $3.79 \pm 2.04$ days, and $3.33 \pm 2.00$ days, respectively. There was no statistically significant difference between age groups in terms of hospitalization times (p:0.392).

During hospitalization, 39 (18.57\%) patients had severe dehydration and 128 (60.95\%) patients had moderate dehydration. Hypernatremia (sodium>145 $\mathrm{mEq} / \mathrm{L}$ ) was detected in 2 patients (0.95\%) and hyponatremia (sodium <132 mmol/L) in 20 patients (9.52\%). 12 (5.71\%) patients had prerenal insufficiency (urea $>42 \mathrm{mg} / \mathrm{dL}$ ). AST elevation and ALT elevation were 1detected in $141(67.14 \%)$ and 28 (13.31\%) patients with rotavirusinduced gastroenteritis, respectively. Convulsions due to rotavirus were detected in 4 patients. Neutropenia was detected in 11 (5.23\%) patient.

The laboratory results of our patients are shown in Table 2. WBC, urea level, creatinine level, AST, ALT, MPV, NLR and PLR levels of study patients were found to be statistically higher than control group. Neutrophil counts, $\mathrm{Na}, \mathrm{K}$ levels of the patients were statistically lower than control group. The comparison of laboratory findings according to age groups is shown in Table 3 . There was no statistically significant difference between age groups in terms of platelet count and lymphocyte count.

\begin{tabular}{|c|c|c|c|}
\hline & $\begin{array}{c}\text { Patient Group } \\
\text { Mean } \pm S D\end{array}$ & $\begin{array}{c}\text { Control Group } \\
\text { Mean } \pm S D\end{array}$ & $\mathbf{P}$ \\
\hline WBC (K/uL) & $10.22 \pm 3.89$ & $9.18 \pm 2.11$ & 0.001 \\
\hline Hemoglobin (gr/dL) & $12.63 \pm 1.25$ & $12.72 \pm 12.72$ & 0.311 \\
\hline Hemotocrit (\%) & $38.27 \pm 3.05$ & $38.18 \pm 3.02$ & 0.571 \\
\hline MCV (fL) & $74.28 \pm 4.77$ & $75.82 \pm 4.93$ & 0.251 \\
\hline$M P V^{*}(f L)$ & $9.54 \pm 0.79$ & $9.19 \pm 0.67$ & 0.001 \\
\hline Platelet (K/uL) & $377.60 \pm 126.07$ & $371.55 \pm 81.57$ & 0.577 \\
\hline Neutrophil (K/uL) & $5.29 \pm 3.35$ & $3.55 \pm 1.47$ & 0.001 \\
\hline Lymphocyte (K/uL) & $3.81 \pm 2.67$ & $4.19 \pm 1.16$ & 0.510 \\
\hline Urea (mg/dL) & $24.15 \pm 12.30$ & $22.13 \pm 6.01$ & 0.025 \\
\hline Creatinine (mg/dL) & $0.46 \pm 0.10$ & $0.44 \pm 0.11$ & 0.029 \\
\hline $\mathrm{Na}(\mathrm{mEg} / \mathrm{L})$ & $135.46 \pm 3.42$ & $137.63 \pm 2.33$ & 0.001 \\
\hline $\mathrm{K}(\mathrm{mEg} / \mathrm{L})$ & $4.22 \pm 0,50$ & $4.33 \pm 0.37$ & 0.023 \\
\hline Calcium (mg/dL) & $9.82 \pm 0.54$ & $9.92 \pm 0.42$ & 0.211 \\
\hline AST (U/L) & $47.62 \pm 18.68$ & $28.80 \pm 9.86$ & 0.001 \\
\hline ALT (U/L) & $27.51 \pm 19.45$ & $15.98 \pm 6.34$ & 0.001 \\
\hline $\mathrm{NLR}^{* *}$ & $2.41 \pm 2.79$ & $0.92 \pm 0.50$ & 0.001 \\
\hline PLR $* * *$ & $143.58 \pm 98.27$ & $95.45 \pm 35.54$ & 0.001 \\
\hline
\end{tabular}


Table 3. Comparison of laboratory findings according to age groups

\begin{tabular}{lcccc} 
& $\mathbf{0 - 2 4}$ month & $\mathbf{2 5 - 6 0}$ month & $>\mathbf{6 0}$ month & P \\
\hline WBC & $11.60 \pm 3.83$ & $10.02 \pm 3.96$ & $9.35 \pm 3.19$ & 0.320 \\
Hemoglobin & $11.69 \pm 1.43$ & $12.02 \pm 1.11$ & $13.30 \pm 1.01$ & 0.001 \\
Hemotocrit & $34.74 \pm 3.37$ & $36.15 \pm 2.60$ & $39.12 \pm 3.07$ & 0.001 \\
MCV & $74.63 \pm 5.42$ & $72.51 \pm 4.62$ & $75.53 \pm 3.44$ & 0.001 \\
MPV & $9.70 \pm 0.74$ & $9.48 \pm 0.80$ & $9.65 \pm 0.83$ & 0.193 \\
Platelet & $442.50 \pm 110.39$ & $370.14 \pm 132.88$ & $326.37 \pm 58.62$ & 0.001 \\
Neutrophil & $4.94 \pm 3.23$ & $5.21 \pm 3.40$ & $6.49 \pm 3.05$ & 0.142 \\
Lymphocyte & $5.45 \pm 2.78$ & $3.71 \pm 2.60$ & $1.89 \pm 0.99$ & 0.001 \\
NLR & $1.41 \pm 1.52$ & $2.28 \pm 2.72$ & $4.64 \pm 3.41$ & 0.001 \\
PLR & $110.53 \pm 75.95$ & $139.46 \pm 97.66$ & $214.59 \pm 98.31$ & 0.001 \\
\hline
\end{tabular}

There was no statistically significant difference between groups in terms of WBC, MPV and neutrophil counts. However, there was a statistically significant difference between the three groups in terms of platelet count, lymphocyte count, NLR and PLR levels.

Also, a statistically significant correlation was found in patient group, when the correlation test was performed in terms of PLR and NLR (p:0.001, r:0.741). Correlation relationship between NLR and PLR is shown in Graph 1. There was also a statistically significant difference between MPV and PLR when correlated ( $p: 0.021, r: 0.120)$. No statistically significant difference was found according to the correlation test between NLR, PLR and MPV values in terms of patients' length of hospitalization.

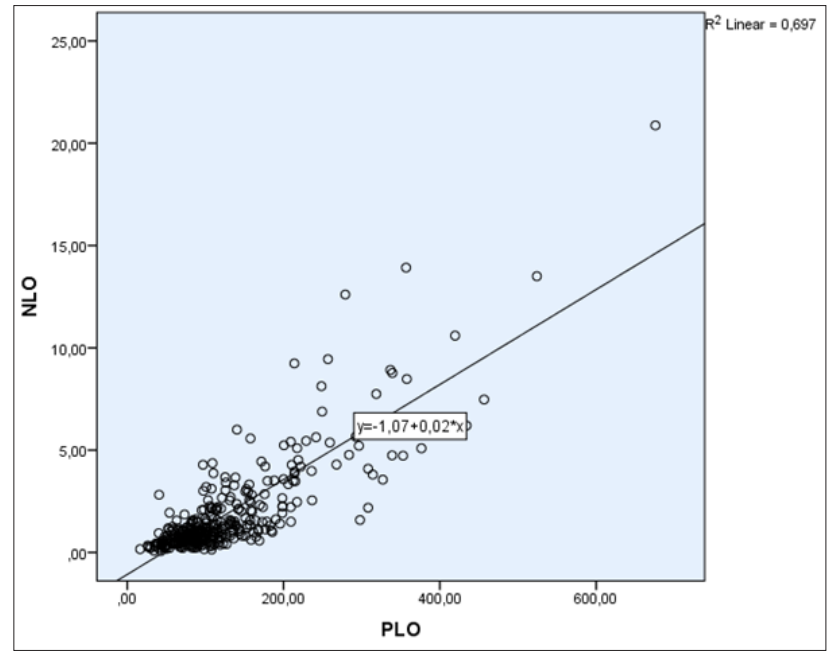

Graph 1. Correlation relationship between NLR and PLR

\section{DISCUSSION}

Rotaviruses are the most common cause of viral gastroenteritis among infants and children. Unlike other infectious agents that cause gastroenteritis, rotavirus occurs with similar frequency in both developed and developing countries regardless of the hygiene conditions and socioeconomic statuses (10). In other words, Rotavirus gastroenteritis leads to morbidity and economic loss in developed countries whereas, mortality in developing countries where the treatment options are inadequate (11).
As the acute viral gastroenteritis is very common in children, the prognosis and complications of the disease can not be foreseen and urgent treatment is required, the use of various markers has come into use in order to prevent unnecessary use of drugs. We considered it appropriate to compare rotavirus gastroenteritis with MPV, NLR, PLR.

Cytokines can play an important role in triggering immunological and inflammatory reactions in rotavirus infection. High IL-6, IL-10, IFN- $\gamma$, IFN- $\alpha$ and TNF- $a$ levels have been reported in clinical trials in children with rotavirus infection (12). Sugata et al. reported6 that IL-8 had a significant positive correlation with rotavirus antigen levels, whereas IL-10 had a significant negative correlation. TNF- $\beta$, also known as lymphotoxin-a, which is released by Th1 helper cells and CD8 cytotoxic T cells, may stimulate macrophage activation and circulation at the infected sites by enhancing the cytotoxic $T$ cell response. TNF- $\beta$ shares receptors with TNF- $\alpha$ and has overlapping effects on peripheral lymphoid tissues and the immune response.

Recently, NLR and PLR values have been associated with systemic inflammatory response in malignancies, diabetes mellitus, coronary artery disease, inflammatory rheumatic diseases $(13,14)$. In systemic inflammation, circulating lymphocyte counts decrease, neutrophilia and thrombocytosis occur. Neutrophilia occurs by stimulation of stem cells via apoptosis delay, neuthrophil demargination and growth factors. Increased number of neutrophils, at higher NLR levels, resulted in increased inflammation and, lower lymphocyte counts were associated with general health disorder, increased cortisol levels due to physiological stress, and increased apoptosis (15). Neutrophils activated by tissue destruction; release some enzymes such as myeloperoxidase, acid phosphatase, and elastase. During the inflammatory response, changes in the proportion of circulating leukocytes occur. Neutrophilia is accompanied by relative lymphopenia. NLR is suggested as a simple marker of inflammatory response (16).

Neutrophils play a major role in host response to acute and chronic infections (17). In recent studies, NLR has been reported as a potential factor of inflammation in many cardiac and non-cardiac diseases (18). Neutrophils play a critical role in immune response of host defense against inflammation. It has also been reported that NLR is used in the assessment of inflammatory response in many cardiac, inflammatory, tumoral and autoimmune diseases as well as a potential predictor of the prognosis for these diseases (19). In a study conducted by Bağlam et al. (20), NLR ratio was significantly higher in patients diagnosed with deep neck infection secondary to acute bacterial tonsillitis compared with patients diagnosed with acute bacterial tonsillitis who did not develop deep neck infection. 
In the literature, there aren't any studies regarding NLR and PLR in patients with rotavirus gastroenteritis. In our study, we found that there is a statistically significant difference in NLR and PLR, between patients with rotavirus gastroenteritis and control group. There was no correlation between hospitalization time of patients and parameters of NLR and PLR. Therefore, we think that it may be instructive for patients with rotavirus associated gastroenteritis.

Platelets are closely related to homeostasis, inflammation, immunity, tissue regeneration and other physiological and pathological processes (21). Platelets play an important role in the pathogenesis of local and systemic inflammation. Thrombotic and inflammatory agents released from platelets can trigger diseasespecific complications (22). Increase in platelet count is an expected situation in active inflammation. MPV is an indication of platelet function and activation; larger platelets are more active. It has long been known that MPV is an inflammatory marker. MPV gives information about platelet size and activity and is used as a measure of platelet dysfunction. Larger thrombocytes are thought to be more active and tend to be aggregated, thus leading to endothelial dysfunction. MPV has long been recognized as an inflammatory marker and has previously been shown to be effective in the treatment of diseases such as familial mediterranean fever, fatty liver disease and atherosclerosis, kidney diseases, inflammatory bowel disease, liver disease and amebiasis (23-28).

MPV pretends to be a negative or positive acute phase reactant in different inflammatory conditions depending on the severity of systemic inflammation29. It is hypothesized that MPV may increase in low grade inflammation due to the presence of large circulating platelets and that MPV may decrease in more severe inflammation due to consumption of these large platelets at the vascular segments in the inflammatory region (29,30). Decreases in MPV levels have been seen particularly in inflammatory gastrointestinal diseases such as inflammatory bowel disease, acute appendicitis, acute gastroenteritis and intestinal tuberculosis (26,30-32). Although the pathogenesis of this reduction in MPV in intestinal inflammation is not fully explained, it seems reasonable to explain this by the entrapment of large active platelets in the vascular segments of the inflamed intestine.

This study demonstrated that MPV levels in children with rotavirus gastroenteritis were significantly higher than the healthy control group. There are only three studies in the literature investigating MPV levels in patients with acute gastroenteritis $(28,30,33)$. Mete et al. showed that MPV levels were lower in children with rotavirus gastroenteritis than healthy children of the same age (30). In another study, Matowicka-Karna et al. found similar results in patients infected with entamoeba histolytica (28). However, Çelik et al. found that the MPV level was higher than the control group in their study with 76 participants (33). We also found that the MPV level was higher in children with rotavirus gastroenteritis than the healthy control group, in our study, similar to the study of Çelik et al. This difference between studies may be due to different levels of disease severity in these studies. We think that the severity of the illness has increased in our study population because of the moderate to severe dehydrated patients admitted to our hospital. This contrary relationship may also be due to the consumption of large platelets in the inflammation site, impairment of thrombopoiesis or increased destruction of circulating platelets (29).

In this study, MPV levels in the patient group were negatively correlated with platelet counts. Although both platelet counts and MPV levels are accepted as acute phase reactants, this inverse relationship is frequently described in some pathologic conditions and reflects an effort to maintain homeostasis by maintaining stable platelet mass $(23,24,30)$. This inverse relationship may be due to large platelet consumption in severe inflammatory conditions, failure in thrombopoiesis or swelling of circulating platelets in an environment with rich active ingredients (29). Prospective studies are needed to clarify the clinical significance of conflicting results.

There are some limitations in our study. Since this study was retrospective, we could not observe the changes in parameters and post-disease changes. We did not measure cytokine levels. To obtain clearer data, prospective studies are needed to show the changes in the levels of hematologic parameters before and after treatment.

\section{CONCLUSION}

We found that MPV, NLR and PLR values are statistically significantly higher in patients with rotavirus associated gastroenteritis than healthy controls. We think that MPV, NLR and PLR parameters will be a guide to understand the systemic involvement of patients with rotavirus gastroenteritis, and to predict the course and complications of the disease. However, we think that there is a need for prospective studies involving more patients in this regard.

\section{ETHICAL DECLARATIONS}

Ethics Committee Approval: Ethics committee approval of the study was taken from the ethics committee of Selçuk University (Permission granted: .......... Decision no: ............).

Informed Consent: Because the study was designed retrospectively, no written informed consent form was obtained from patients.. 
Referee Evaluation Process: Externally peer-reviewed. Conflict of Interest Statement: The authors have no conflicts of interest to declare.

Financial Disclosure: The authors declared that this study has received no financial support.

Author Contributions: All of the authors declare that they have all participated in the design, execution, and analysis of the paper, and that they have approved the final version.

\section{REFERENCES}

1. Parashar UD, Hummelman EG, Bresee JS, Miller MA, Glass RI. Global Illness and Deaths Caused by Rotavirus Disease in Children. Emerg Infect Dis 2003; 9: 565-72.

2. Kaşifoğlu K, Us T, Aslan F, Akgün Y. 2005-2011 Yılları Arasında Saptanan Rotavirus Antijen Pozitiflikleri. Türk Mirobiyoloji Cem Derg 2011; 41: 111-5.

3. Parashar UD, Burton A, Lanata C, et al. Global mortality associated with rotavirus disease among children in 2004. J Infect Dis 2009; 200: 9-15.

4. Liu B, Fujita Y, Arakawa C, et al. Detection of rotavirus RNA and antigens in serum and cerebrospinal fluid samples from diarrheic children with seizures. Jpn J Infect Dis 2009; 62: 279-83.

5. Ray P, Fenaux M, Sharma S, et al. Quantitative evaluation of rotaviral antigenemia in children with acute rotaviral diarrhea. $J$ Infect Dis 2006; 194: 588-93.

6. Sugata K, Taniguchi K, Yui A, et al. Analysis of rotavirus antigenemia and extraintestinal manifestations in children with rotavirus gastroenteritis. Pediatrics 2008; 122: 392-7.

7. Chiappini E, Galli L, de Martino M. Viremia and clinica manifestations in children with rotavirus infection. J Infect Dis 2006; 193: 33.

8. Blutt SE, Matson DO, Crawford SE, Staat MA, Azimi P, Bennett BL, et al. Rotavirus antigenemia in children is associated with viremia. PLoS Med 2007; 4: 121.

9. Azevedo MS, Yuan L, Pouly S, et al. Cytokine responses in gnotobiotic pigs after infection with virulent or attenuated human rotavirus. J Virol 2006; 80: 372-82.

10. Bozdayı G, Doğan B, Dalgıç B, et al. Diversity of human rotavirus G9 among children in Turkey. J Med Virol 2008; 80: 733-40.

11. Kurugol Z, Salman N. Rotavirus enfeksiyonları ve aşıları. ANKEM derg 2008; 22: 160-70.

12. Jiang B, Snipes-Magaldi L, Dennehy $P$, et al. Cytokines as mediators for or effectors against rotavirus disease in children. Clin Diagn Lab Immunol 2003; 10: 995-1001.

13. Uslu AU, Küçük $A$, Şahin $A$, Ugan $Y$, Yılmaz $R$ et al. Two new inflammatory markers associated with Disease Activity Score-28 in patients with rheumatoid arthritis: neutrophil-lymphocyte ratio and platelet-lymphocyte ratio. Int J Rheum Dis. 2015; 18: 731-5.

14. Sari I, Sunbul M1, Mammadov C, Durmus E, Bozbay M, Kivrak $\mathrm{T}$ et al. Relation of neutrophil-to-lymphocyte and platelet-tolymphocyte ratio with coronary artery disease severity in patients undergoing coronary angiography. Kardiol Pol. 2015; 73: 1310-6.

15. Tzur T, Sheiner E. Is there an association between platelet count during the first trimester and preeclampsia or other obstetric complications later in pregnancy? Hypertens Pregnancy 2013; 32: 74-82.

16. Zahorec R. Ratio of neutrophil to lymphocyte counts- Rapid and simple parameter of systemic inflammation and stress in critically ill. Bratisl Lek Listy 2001; 102: 5-14

17. Amulic B, Cazalet $C$, Hayes $G L$, et al. Neutrophil function: from mechanisms to disease. Ann Rev Immunol 2012; 30: 459-89.

18. Nunez J, Nunez E, Bodi $V$, et al. Usefulness of the neutrophil to lymphocyte ratio in predicting long-term mortality in ST segment elevation myocardial infarction. Am J Cardiol 2008; 101: 747-52.

19. IIlhan M, Illhan G, Gök AF, et al. Evaluation of neutrophillymphocyte ratio, platelet-lymphocyte ratio and red blood cell distribution width-platelet ratio as early predictor of acute pancreatitis in pregnancy. J Matern Fetal Neonatal Med 2015; 5: $1-5$.
20. Baglam T, Binnetoglu A, Yumusakhuylu AC, et al. Predictive value of the neutrophil-to-lymphocyte ratio in patients with deep neck space infection secondary to acute bacterial tonsillitis. Int J Pediatr Otorhinolaryngol 2015; 79: 1421-4.

21. Ware J, Corken A, Khetpal R. Platelet function beyond hemostasis and thrombosis. Curr Opin Hematol 2013; 20: 451-6.

22. Jenne CN, Urrutia R, Kubes P. Platelets: bridging hemostasis, inflammation, and immunity. Int J Lab Hematol 2013; 35: 254-61.

23. Makay B, Turkyilmaz Z, Unsal E. Mean platelet volume in children with familial Mediterranean fever. Clin Rheumatol 2009; 28: 9758.

24. Arslan N, Makay B. Mean platelet volume in obese adolescents with nonalcoholic fatty liver disease. J Pediatr Endocrinol Metab 2010; 23: 807-13.

25. Catal F, Bavbek N, Bayrak O, et al. Platelet parameters in children with upper urinary tract infection: Is there a specific response? Ren Fail 2008; 30: 377-81.

26. Öztürk ZA, Dag MS, Kuyumcu ME, et al. Could platelet indices be new biomarkers for inflammatory bowel diseases? Eur Rev Med Pharmacol Sci 2013; 17: 334-41.

27. Purnak T, Olmez $S$, Torun $S$, et al. Mean platelet volume is increased in chronic hepatitis $C$ patients with advanced fibrosis. Clin Res Hepatol Gastroenterol 2013; 37: 41-6.

28. Matowicka-Karna J, Panasiuk A. Does anti-parasitic treatment normalize platelets morphology in patients infested with Entamoeba histolytica? Rocz Akad Med Bialymst 1996; 41: 25867.

29. Gasparyan AY, Ayvazyan L, Mikhailidis DP, et al. Mean platelet volume: A link between thrombosis and inflammation? Curr Pharm Des 2011; 17: 47-58.

30. Mete E, Akelma AZ, Cizmeci MN, et al. Decreased mean platelet volume in children with acute rotavirus gastroenteritis. Platelets 2013; 25: 51-4.

31. Bilici S, Sekmenli T, Göksu M, et al. Mean platelet volume in diagnosis of acute appendicitis in children. Afr Health Sci 2011; 11:427-32.

32. Huang S, Yi FM, Zhou R, et al. The utility of platelet, mean platelet volume, and red cell distribution width in the diagnosis of active Crohn's disease and intestinal tuberculosis. Saudi Med J 2013; 34: 1161-6.

33. Celik T, Güler E, Atas BE et al. Mean Platelet Volume as a Negative Marker of Inflammation in Children with Rotavirus Gastroenteritis. Iran J Pediatr Oct 2014; 24: 617-22. 